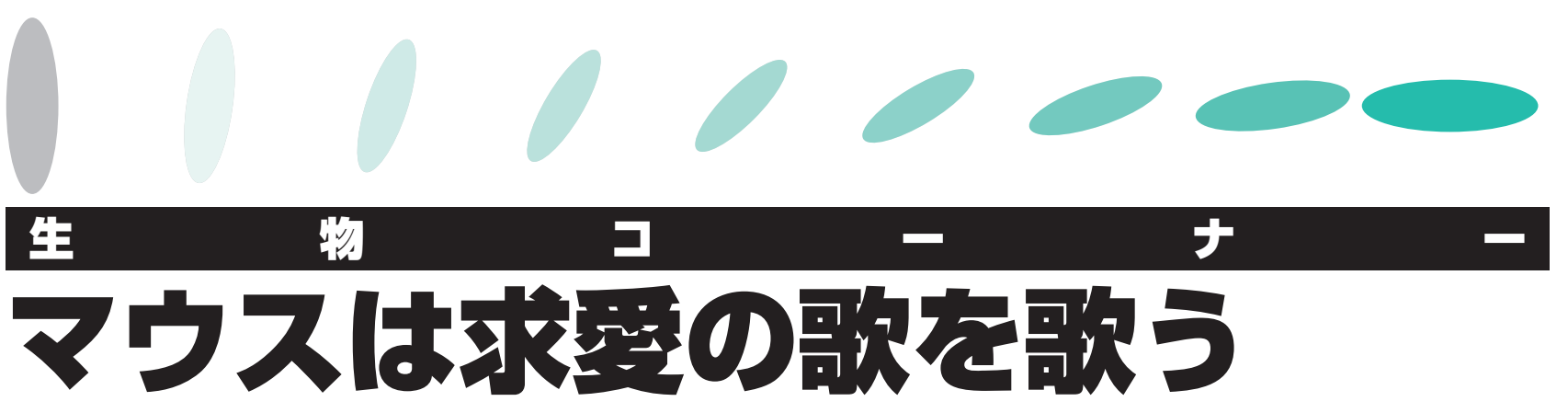

動物の世界，動物の行動はまだまだ 解き明かせない謎に満ち溢れている. たとえば，世界中には様々な形，色， 鳴き声をもつ鳥が数多くいる，鳥類の 中でも鳴禽類は別名歌鳥類とも呼ばれ るほど，そのさえずりが美しく，長年 世界各地で愛玩用として繁殖されてき た. 身近なものとして, カナリア, ジュウシマツ, ブンチョウなど日本で 馴染みの深いものから, フィンチ類な ど海外で人気のものもある。これらの 鳥はその名に示すように，繁殖期にな るとオスがメスに向かって歌（さえず り）を歌うことが知られている.これ までの研究から, これら鳴禽類の歌の 特徴は, ヒトが話し言葉を学ぶのと似 ていることが明らかとなっている.

ヒトの言語学習は幼少期に親や周囲 から言語の規則などを, 模倣しながら
学ぶ.これを音声学習という。英語に 触れた子供は英語を自然と身につける というイメージだろうか。私たちが日 頃何気なく使っている言語では, 文法 と意味は不可分に結合して, 全体とし て使われている，進化の過程を想像す ると，言葉をもつ以前の人間は，さま ざまな状況に合わせてさまざまな歌を 歌っていたと想定される。この「歌」 がより多様化する過程で, 状況（意 味）の共通部分と歌（文法）の共通部 分が相互に分節化され, 切り出される ことで，より限定された意味をもつ 「単語」が生じた可能性が指摘されて きた. 東京大学の岡ノ谷一夫先生らは これを「歌と文脈の相互分節化仮 説」(1) と呼び, 現在も「言語の進化」 を解き明かそうと邁進されている。 そ して，そのような音声学習をする動物
として, 唯一のモデル動物と考えられ てきたのが鳴禽類である.

実は, 歌を歌う動物は他にもいる. 2005年にT. Holyらは, マウスでもヒ トには聞こえない高い超音波領域の声 を使って, 雄マウスが雌マウスに歌を 歌うことを明らかにした ${ }^{(2)}$ 。それを契 機に，マウスの歌に関して，どれほど 多様性があるのか, その多様性が遺伝 子によるものか, それとも幼少期の音 声学習によるものなのか, の議論が世 界中に広がっていった。その背景に は,「言語」という唯一無二の社会機 能をもつヒトの研究において，鳥類で はなく哺乳類であり, それも遺伝的に 操作が可能なマウスの歌学習が確認さ れれば, 言語中枢の研究が飛躍的に発 展するとの期待があったからである.

私たちのラボでも，まずはその多様

\section{C57BL6 マウス}

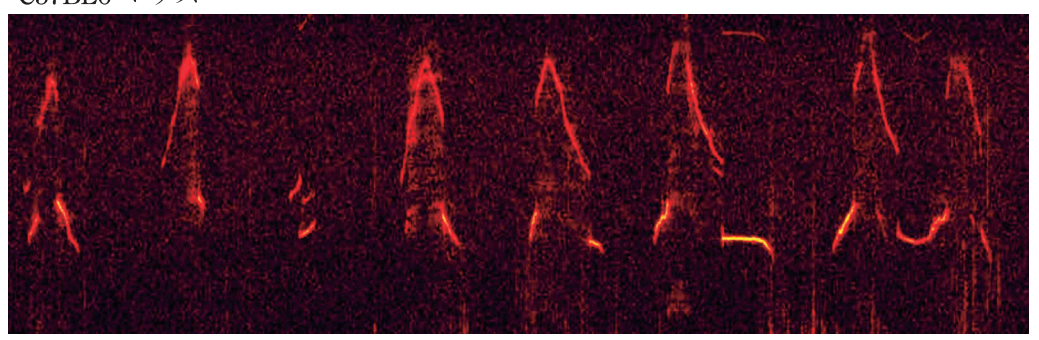

$\mathrm{BALB} / \mathrm{c}$ マウス

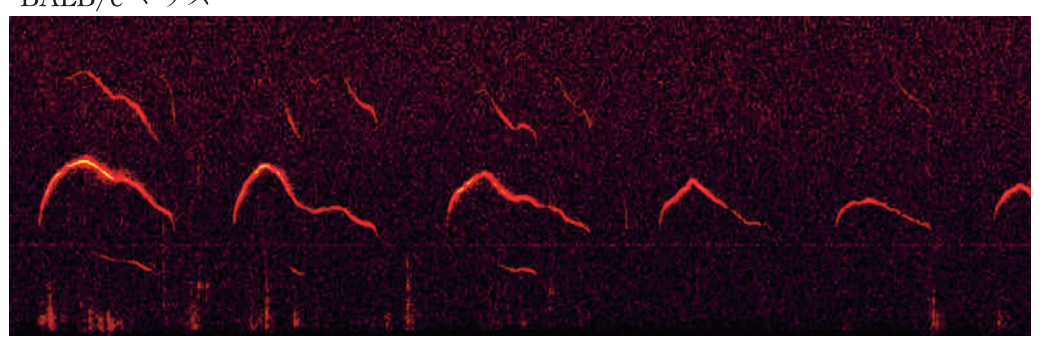

図 1 -C57BL6 マウスと BALB/c マウスの求愛歌 のソノグラム

C57BL6マウスでは1つのシラブルの中に大きな周 波数のジャンプが含まれるものが多数あるのに対し て, BALB/cマウスでは少し長めのシラブルで, ハーモニックスと呼ばれる倍音の音声が見て取れ る. 


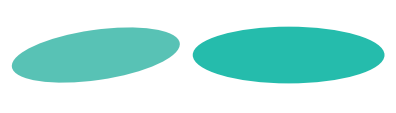

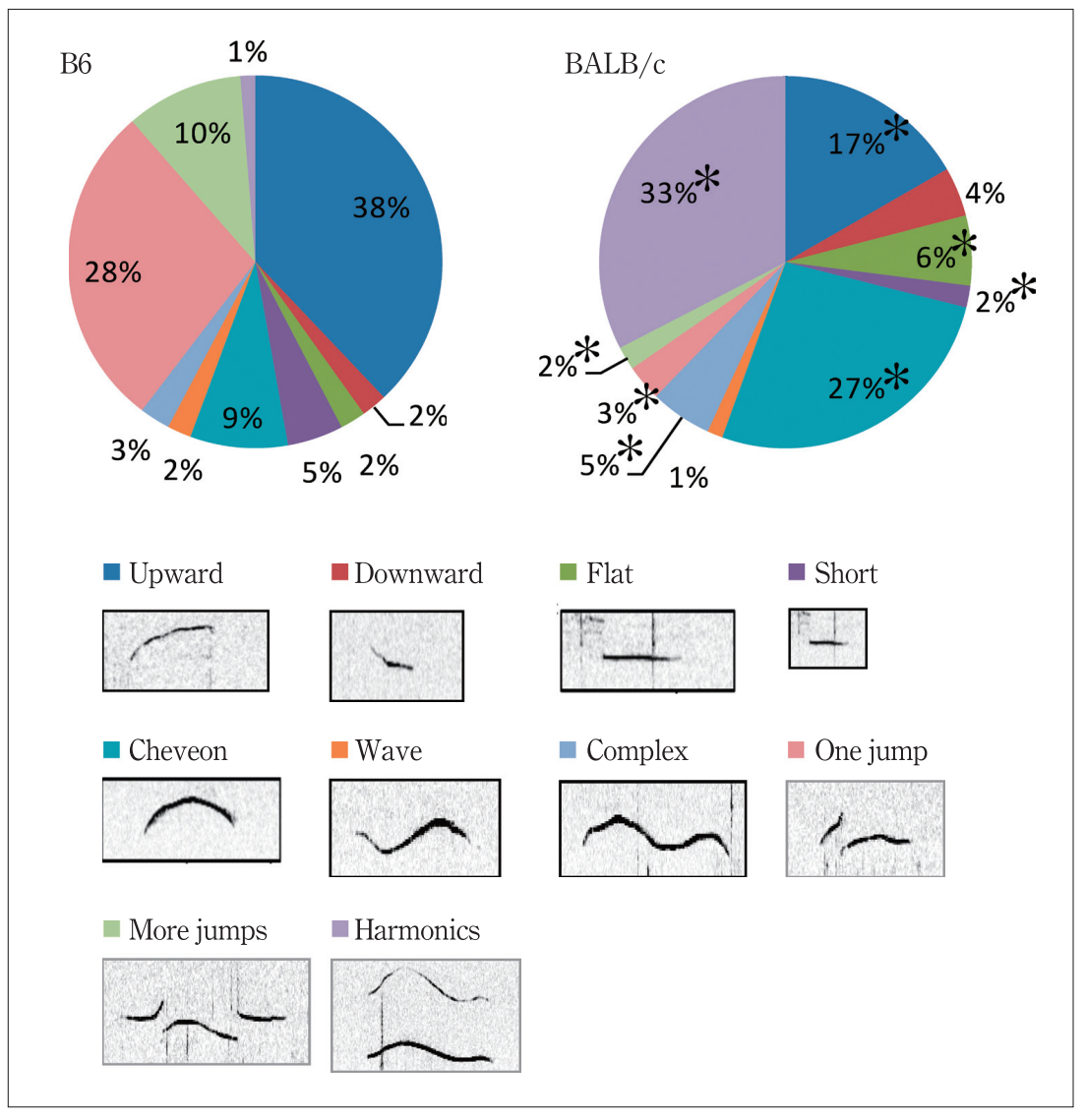

性を調べようと,2系統のマウス (C57BL6とBALB/c) の歌構造を調 べた（図1）。予想通り，その歌は大 きく異なっていた．歌のシラブルと呼 ばれる音節の出現のパターン, さらに その出現の頻度も大きく異なっていた (図2). 次に, これら2系統のマウス に出生後間もなく里子操作を施し, 発 達期における音声環境を逆転させてみ た.このことで, 環境から学習する音 声であるとすれば, ヒトの言語のよう
に育ての親の歌に似た声で歌うことに なるはずだ. しかし，里子操作によっ ても, これら 2 系統の歌の特徴は維持 され，それぞれが遺伝的な親の歌と同 じ歌を歌うこと,つまり複雑な歌が遺 伝的に制御されていることが明らかと なった ${ }^{(3)}$.

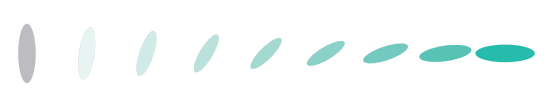

では, その歌の多様性はいかほどの
図 2・C57BL6（B6）マウスとBALB/c マウスのシラブル発現率の違い

すべてのシラブルを 10 種類に分類し（下 段)，その発現率を円グラフで示した，B6 マウスではupward と one jump, more jumpsのシラブルが多いのに対して, BALB/c マウスでは cheveon と harmonics のシラブルが多く発現し, その歌構造が 異なることが示された。 ${ }^{*} \mathrm{~B} 6$ と BALB/c の間での有意差を示す。

ものであろうか. 国立遺伝学研究所の 小出剛先生との共同研究で, 世界各地 から捕獲された野生マウスでその歌の 構造を調べてみた。韓国からは KJR, 日本からはMSM とJF-1, フランスか

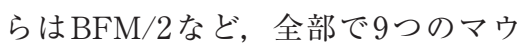
スの系統を調べてみたところ, 各マウ スの系統間に打いてシラブルの出現頻 度が大きく異なっていた。 このシラブ ルの出現頻度が遺伝的に制御されてい る可能性はすでに記載したが, 遺伝的 
距離と同じょうな類似性，つまり遺伝 的に近いマウスの系統間では似通った シラブルになり，遺伝的に遠い系統間 では異なったシラブルになるだろうと の予想のもと, 調べてみた。驚くこと に，遺伝的距離と歌の構造との間には 一貫性がなく, 歌の構造自体は遺伝的 支配を受けているにもかかわらず，歌 の進化の過程には強い淘汰圧がかかっ ていないことが明らかとなった，淘汰
圧が少ない状態での進化として遺伝的 浮動が知られているが，抒そらくマウ スの歌構造に関しては, この遺伝的浮 動が関わっているのであろうと考えら れた ${ }^{(4)}$.

では，遺伝的にある程度規定されて いるこの歌の意味，つまり歌はちゃん
とメスマウスを魅了する能力をもちう るか，を調べてみた。まずは様々な系 統のオスをメスに出会わせて, 歌の発 現を調べた。その際，メスの性行動や オスからのアプローチを拒絶する行動 を観察した。そうすると，メスはある タイプの歌（High2-4）に対してはあ まり拒絶を示さず，むしろアプローチ する様子が見られた，逆に，ある夕イ プの歌（Low2-4）の場合はほとんど拒

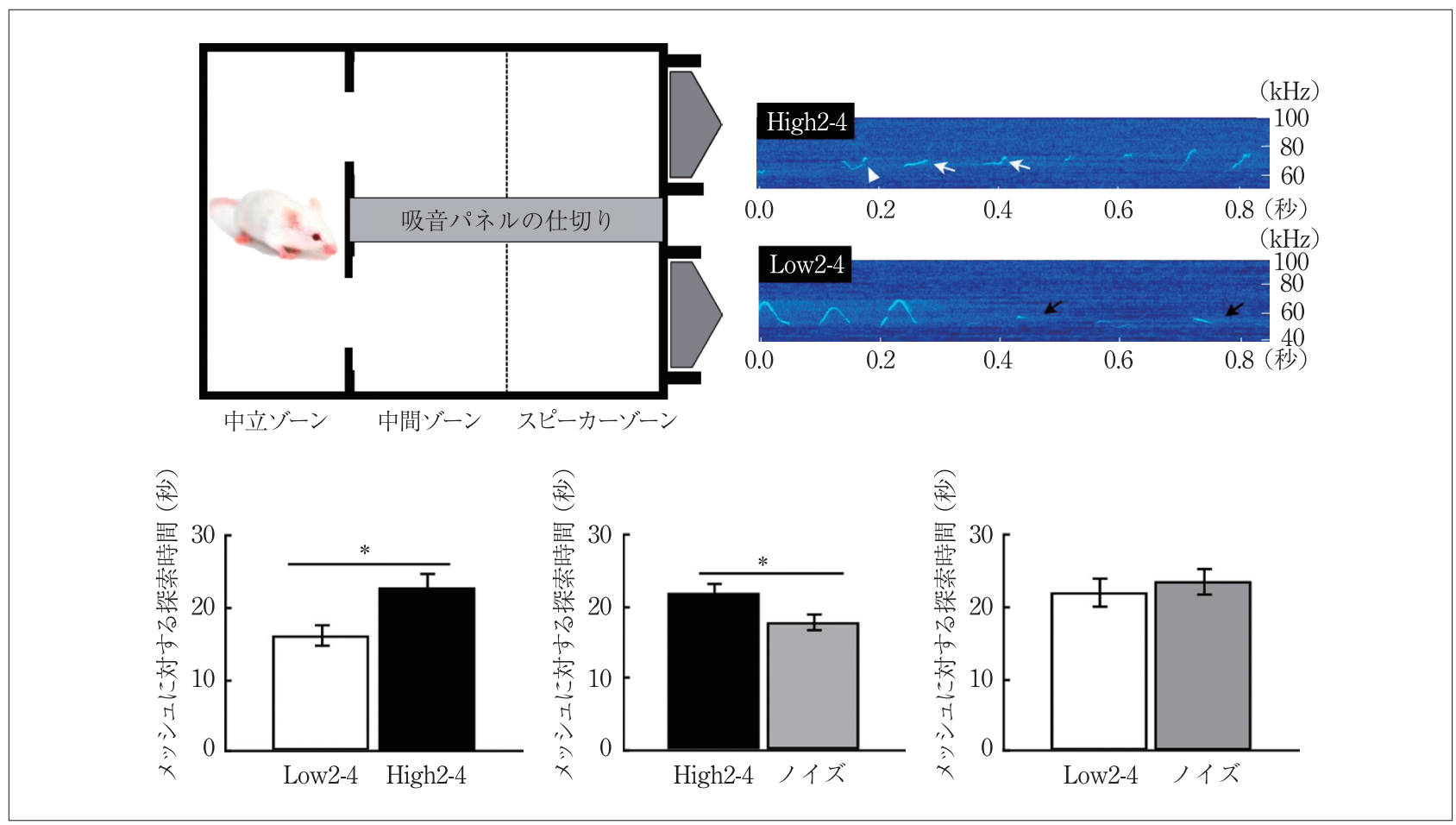

図3・メスマウスの嗜好性試験

3つのコンパートメントに区切られたテスト箱（左上）にメスマウスを導入し，2つのスピーカーから同時に異なったオスの求愛歌を再生 した．再生した音声を右上に示す．High2-4ではシラブルの後半で周波数が高くなるものが多く含まれ，逆にLow2-4では周波数が低下する 短いシラブルが多く認められる。これらを再生すると, メスマウスは有意にHigh2-4へのアプローチを示し，嗜好性が認められた。これは ノイズ音に対しても同じように認められ，またLow2-4はノイズと同じレベルの嗜好性となった。*統計的に有意差あり. 
絶行動だけを示していた。一生懸命 歌っているオス，それでも拒絶だけさ れてしまう様子は，なんとも少し哀れ な気持ちになる。

さて, そのメスの行動の変化が実際 の歌という音声刺激で制御されている かどうかこの時点では不明である。 も しかしたらオスの匂いかもしれない し，あるいはオスのアプローチの仕方 に問題があったのかもしれない，そこ で, 音声だけの刺激でメスの行動が変 わるか否かを調べるための再生実験を 行なった。

メスマウスを $2 つ の$ 音声が再生され るテストケージに入れて, 同時に 2 種 類の歌を再生した。一つはメスマウス が好むと思われる歌，もう一つはメス マウスが拒絶行動を示していたときの 歌である. 図了に示したと㧍り，これ ら2つの歌には形の異なったシラブル が含まれていること (図中矢印)，好 まれるほうの High2-4にはシラブルの 最後で周波数が少し高くなるものが多 く含まれているのに対して, Low2-4 には短く, 多少周波数が低下するシラ ブルが含まれていた.

この $2 つ の$ 歌を再生すると, メスマ ウスはHigh2-4に対して近づいてい き，スピーカーの前にあるメッシュに 対して探索する行動を示し，その值は Low2-4の場合に比べて有意に高かっ た。さらにHigh2-4をノイズと比較し ても，High2-4に対する探索時間は有 意に長いことが明らかとなり, High2-4の歌の中には確かにメスを惹
きつける特異的な音声成分が含まれて いることが示されたわけである(4).

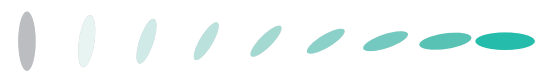

実は，私たちがこれら研究発表を行 なったと同時期に, アメリカNortheastern Ohio Universities の Grimsley 博士らはマウスの歌構造の発達に関す る論文を発表した。彼女らはCBA と いうマウスを用いて，生後5日から 7 日，9日，11日，さらに成長後の超音 波音声を録音解析した。すると，子マ ウスは発達に従って, 非常に特徴的な 変化を見せた．たとえば，周波数はは じめ, かなり変化に富んだ音声を出し ており, 高いものは $150 \mathrm{kHz}$ から, 低 いものは $50 \mathrm{kHz}$ くらいまでであった. 成長すると, これがほほ一点の $80 \mathrm{kHz}$ に集中するようになって㧍り， 音声の多様性が縮小してくるらしい。

また波形パターンは，生後間もない 時期にはフラットな形あるいはシラブ ルの中で 1 回の周波数ジャンプを含む ものが多かったが，成長すると周波数 が上昇しながら倍音を含むようなシラ ブルの発現頻度が上昇してきた．並行 して, シラブルの持続時間は大人にな るにつれて短くなっていった。

これらのことから Grimsley 博士ら は，マウスが周囲環境にあわせて次第 に音声を記憶し，その記憶をもとに音 声が変化したのではないかと考察して いる(5).

一見私たちの結果とは反するように
見えるが，実際に私たちのラボでも発 達変化を追跡したことがある。 その結 果, Grimsley博士らと同じょうに, C57BL6やBALB/cのマウスでも発達 に伴う音声の劇的な変化が観察され た。しかし，里子に出したり，あるい は强制的に見知ら妨入の歌に曝露 したりと, 音声環境を変化させても, 子マウスの音声発達には影響が認めら れなかった。このことから，マウスは 発達に伴って, その音声の発現パ夕ー ンを変化させていくものの，これもほ とんどが遺伝的にプログラムされた発 声パターンであると思われる。

今回の研究は, 生物言語研究におい て小さなしかし確実な一歩となったで あろう。残念ながら，マウスの歌は ちゃんと歌構造をもっているものの, その多様性は音声学習を経て得られる ものではなく，遺伝的支配の強いもの であることが明らかになった。このこ とから，ヒトの言語モデルとしてのマ ウスの歌解析の価值は下がるといえる であろうが，しかしこの多様性に富ん でいるマウスの歌が，どのような遺伝 子によって決定されているのかとい う，新たな，そして大きな命題が次の テーマとなろう.

2001年にAnthony Monaco 教授の 率いる研究チームは, 遺伝的に言語障 害をもつヒトの家系から言語に関係す ると推定される遺伝子を同定し, 
FOXP2遺伝子と名づけた ${ }^{(6)}$.この遺 伝子はオランウータン, ゴリラ, チン パンジー, マウスでもほぼ同じ形で保 存されていることから, マウスでの機 能解析も進んでおり, この遺伝子を人 為的に欠損させたマウスでは, 超音波 発声が変化することが知られてい る ${ }^{(7)}$.また, 国立遺伝学研究所では, 日本固有種であるMSMマウスと C57BL6マウスによるコンソミックマ ウスを維持している. コンソミックマ ウスとは, 常染色体のうち, 1つだけ が他の系統のマウスのものと入れ替え られているもので, 順行遺伝学におい てよく使われる手法である。これを用
いると, 複雑な歌のどの要素がどの染 色体上にマップされてくるかが見えて くるはずである。またその他にも，マ ウスの求愛歌をモデルに, 複雑な音声 がどのように中枢で遺伝的に制御され ているかを解析する研究は, 言語障害 や自閉症のような発達性障害に認めら れる言語獲得のモデルとしても価值が 高く, 言語遺伝子と歌の関係性の研究 が今後大きく発展することを期待した い.

1）岡ノ谷一夫：“さえずり言語起源論 一小鳥の歌からヒトの言葉へ”, 岩 波科学ライブラリー, 2010.

2) T.E. Holy \& Z. Guo: PLoS Biol., e386 (2005).
3) T. Kikusui, K. Nakanishi, R. Nakagawa, M. Nagasawa, K. Mogi \& K. Okanoya:PLoS One, e17721 (2011).

4) H. Sugimoto, S. Okabe, M. Kato, N. Koshida, T. Shiroishi, K. Mogi, T. Kikusui \& T. Koide: PLoS One, e22093 (2011).

5) J. M. Grimsley, J. J. Monaghan \& J. J. Wenstrup : PLoS One, e17460 (2011).

6) C. S. Lai, S. E. Fisher, J. A. Hurst, F. Vargha-Khadem \& A. P. Monaco: Nature, 413, 519 (2001).

7) D. F. Newbury \& A.P. Monaco: Neuron, 68, 309 (2010).

(菊水健史, 麻布大学獣医学部)

\section{プロフィル}

辻尚 利 (Naotoshi Tsuji) <略歴> 1989年日本獣医畜産大学獣医畜産学部獣 医学科卒業／同年農林水産省家畜衛生試験 場研究員／1998年同試験場主任研究官／ 2006 年 (独) 農研機構動物衛生研究所主任 研究員 ( 現在) / 2007年東京大学大学院 農学生命科学研究科連携併任准教授 ( 現 在) $/ 2009$ 年帯広畜産大学原虫病研究セン ター客員教授, 現在にいたる.この間, 1996 年米国コロラド州立大学博士研究員. 1995 年獣医博 (北海道大学) <研究テー マと抱負 $>$ Vector-Parasite-Host相互関係 の解明とマダニ媒介性感染症の予防治療薬 開発 $<$ 趣味 $>$ 日本酒

永井和夫 (Kazuo Nagai) <略歴 $>$
1964 年東京大学農学部農芸化学科卒業後, 同大学大学院博士課程修了, (財) 微生物化 学研究所研究員, 東京大学助手, 助教授, 東京工業大学生命理工学部教授を経て, 中 部大学応用生物学部教授, 現在にいたる <研究テーマと抱負 > 生物の生産する生理 活性物質の探索と作用機構の解析<趣味 $>$ 体を動かすこと, 美しいものを楽しむこと

七谷 圭 (Kei Nanatani) <略歴> 2005 年日本学術振興会特別研究員 (DC1) / 2008年東北大学大学院農学研究 科応用生命科学専攻博士課程後期 3 年修 了 $/ 2009$ 年同大学院工学研究科バイオ工 学専攻助教, 現在にいたる.この間, 2008 年米国ジョンズ・ホプキンス大学医学部博
士研究員 $<$ 研究テーマと抱負 $>$ 微生物の膜 輸送と環境ストレス適応機構＜趣味 $>$ 登山

花井泰三（Taizo Hanai）<略歴> 1991 年東北大学工学部化学工学科卒業 / 1996 年名古屋大学大学院工学研究科助 手 $/ 2001$ 年九州大学大学院農学研究院准 教授, 現在にいたる.この間 $2006 〜 08$ 年 米国カリフォルニア大学ロサンゼルス校 (UCLA) 客員研究員<研究テーマと抱 負 $>$ 人工代謝経路を導入して様々な化学物 質を生産する微生物の合成生物学, 発振現 象や理論回路を実現する合成生物学<趣 味>おいしいものを食べること, 旅行, 温 泉 